Mary Beth Babos, PharmD, Joseph D. Perry, BS, Sara A. Reed*, BS, Sandra Bugariu, BS, Skyler Hill-Norby, BA, Mary Jewell Allen, DO, Tara K. Corwell, BS, Jade E. Funck, MS, Kaiser F. Kabir, MS, Katherine A. Sullivan, MS, Amber L. Watson, BS and K. Kelli Wethington, BSN

\title{
Animal-derived medications: cultural considerations and available alternatives
}

https://doi.org/10.1515/jom-2020-0052

Received March 12, 2020; accepted October 20, 2020;

published online March 8, 2021

\section{Abstract}

Context: Cultural competency is a cornerstone of patientcentered health care. Religious doctrines may define appropriate consumption or use of certain animals and forbid use of others. Many medications contain ingredients that are animal-derived; these medications may be unacceptable to individual patients within the context of their religious beliefs and lifestyle choices. Knowledge of animal-derived medications as a component of cultural competency can facilitate a dialogue that shifts focus from the group to the individual, away from cultural competency toward cultural humility, and away from a paternalistic provider/patient dynamic toward one of partnership.

Objectives: To explore how animal-derived drug components may impact medication selection and acceptability from the perspective of patients, physicians, and religious leaders as evidenced by studies that explore the question via survey or questionnaire. A secondary objective is to use the context of animal-derived drug products as a component of cultural competency to build a framework supporting the development of cultural humility.

Methods: A systematic search was performed in the PubMed, CINAHL, Cochrane, and ProQuest databases using combinations of the following terms: "medication

\footnotetext{
*Corresponding author: Sara A. Reed, BS, c/o Mary Beth Babos, Lincoln Memorial University - DeBusk College of Osteopathic Medicine, 6965 Cumberland Gap Parkway, Harrogate, TN 37752, USA, E-mail: sara.reed@lmunet.edu

Mary Beth Babos, PharmD, Joseph D. Perry, BS, Sandra Bugariu, BS, Skyler Hill-Norby, BA, Mary Jewell Allen, DO, Tara K. Corwell, BS, Jade E. Funck, MS, Kaiser F. Kabir, MS, Katherine A. Sullivan, MS, Amber L. Watson, BS and K. Kelli Wethington, BSN, Lincoln Memorial University - DeBusk College of Osteopathic Medicine, Harrogate, TN, USA
}

selection," "medication," "adherence," "pharmaceutical preparations," "religion and medicine," "religion," "animal," "dietary," "porcine," and "bovine." Studies that reported using surveys or questionnaires to examine patient, physician, or religious leader perspective on animal-derived medications published in English between 1990 and 2020 were included. Review articles, opinion pieces, case reports, surveys of persons other than patients, religious leaders, or physicians, and studies published in languages other than English were excluded. Three authors independently reviewed articles to extract information pertaining to perspectives on animal-based medication ingredients.

Results: Eight studies meeting the described criteria were found that queried beliefs or knowledge of patients, religious leaders, or physicians regarding medications and medical products of biologic origin. Those studies are described in full in this review.

Conclusions: Knowledge of animal-derived ingredients may help open conversations with patients around spiritual history and cultural competency, particularly for those patients belonging to religious sects with doctrines that define appropriate use of human- or animal-derived products. Further formal study is needed to explore more fully the extent to which religious beliefs may impact selection of animal- or human-derived medications. Guidelines developed from this knowledge may aid in identifying individual patients with whom the discussion may be particularly relevant. More studies are needed to quantify and qualify beliefs regarding animal-derived medication constituents.

Keywords: animal-derived medications; cultural competency; religion; patient care.

Many physicians report difficulty in initiating conversations about spirituality and religion with their patients $[1,2]$. Religious and spiritual beliefs are intimately interconnected to health beliefs; spiritual concerns are cited as important by nearly all hospitalized patients [1]. A survey of 
230 patients with terminal cancer revealed that $88 \%$ cited attendance to their religious belief by their provider to be at least "somewhat" important [3]. The word "health" itself derives etymologically from the same root as "whole" and "holy" [3]; thus, the domain of spirituality is integral to the principles of patient-centered health care. Conducting a "spiritual history" during clinical encounters can ease initiation of this conversation to support integration of the individual patient's religious, spiritual, or secular beliefs into the treatment plan [4]. It is critical to perform this assessment in a sensitive manner, promoting a safe space where spiritual and religious matters can be discussed, addressed, and integrated [5].

Spiritual history is defined as a "set of questions designed to invite patients to share their religious or spiritual beliefs to help identify spiritual issues." [6] The spiritual history should be used to assess the patient's beliefs that affect coping mechanisms, support systems, and any strong influential ideology that could impact medical decision-making [2, 5]. Performance of the spiritual history is not another checklist to complete, but rather a complex task that requires active listening on the part of the interviewer to elicit the spiritual factors that impact patient health beliefs and outcomes [2]. Many clinicians face difficulty addressing and assessing spiritual needs in practice $[2,7]$. Several tools have been developed to help practitioners invite discussion of patient beliefs, including a systematic review by Lucchetti et al. [7] and an expert panel discussion by Paal et al. [2] As with all aspects of reviewing a patient's history, queries should be respectful to the patient and should avoid any judgmental questioning or spiritual persuasion $[2,7,8]$.

One aspect of patient cultural belief that may impact medical care involves medicines and surgical products derived from animal and human sources [9-11]. A growing consensus is emerging among prescribers regarding the need to inform patients who might object to animal-derived medications $[12,13]$, though prescribers are often unaware that medicines contain animal-derived ingredients [9]. Several nations have published guidelines to address pharmaceuticals of animal origin. The United Kingdom's first guidelines were published in 2004 [14] and Australia's inaugural document, initially published in 2007, was updated in 2019 [15]. In 2018, the American Medical Association House of Delegates passed a resolution recommending efforts to improve cultural awareness of animalderived medication ingredients and encouraged the U.S. Food and Drug Administration (FDA) to make information related to source of medication ingredients accessible [16]. These recommended guidelines from the FDA are not yet available. In the interim, this paper aims to fill the gap, exploring the state of the literature regarding acceptability of biologically-derived medications, drawing attention to common biologic-derived medications and excipients, and opening a discussion to promote the selection of pharmaceuticals in support of individual patient autonomy, selfregulation, and religious or cultural beliefs.

As a competency, cultural competency assumes that a quantifiable set of cultural diversity-related skills can be learned. Limitations to this approach include the fluid nature of culture, "false competence" wherein the culture is being defined from a perspective of privilege outside the context of the culture itself, measurement errors, and the ecologic fallacy that assumes all individuals conform to the norms of the group $[17,18]$. In contrast, cultural humility is a continuous process of awareness that an individual patient's cultural beliefs may impact health behaviors. Like culture itself, cultural humility is a "changing, plastic process" [19] that involves continued self-evaluation for assumptions and bias, active listening to each patient as an individual, and continuous attainment of knowledge [18, 20].

As a systematic review focused on the impact of religious belief on medication selection related to animalderived drug ingredients, the primary objective of this research was to provide quantified categorical information to promote awareness of the importance of the issue. We update and expand upon earlier reports and editorials [9-17] to focus on studies that investigate patient, religious leader, and physician-provider perspectives. We offer brief synopses of beliefs in six major United States' religious sects to identify common beliefs that may impact patient satisfaction with medication selection. We highlight common medications and ingredients that may be problematic, and we offer resources that may help prescribers identify potentially problematic medication constituents and their potential alternatives. We offer this information in the hope the reader uses the knowledge as a foundation from which to engage individual patients in conversations that lead to the bidirectional flow of cultural knowledge necessary for cultural humility-embedded practice.

\section{Methods}

\section{Search strategy}

We followed the Preferred Reporting Items for Systematic Reviews and Meta-Analysis (PRISMA) [21] guidelines for this systematic review, as illustrated in Figure 1. Electronic databases including PubMed, Cumulative Index to Nursing and Allied Health Literature (CINAHL), Cochrane, and ProQuest were searched systematically 


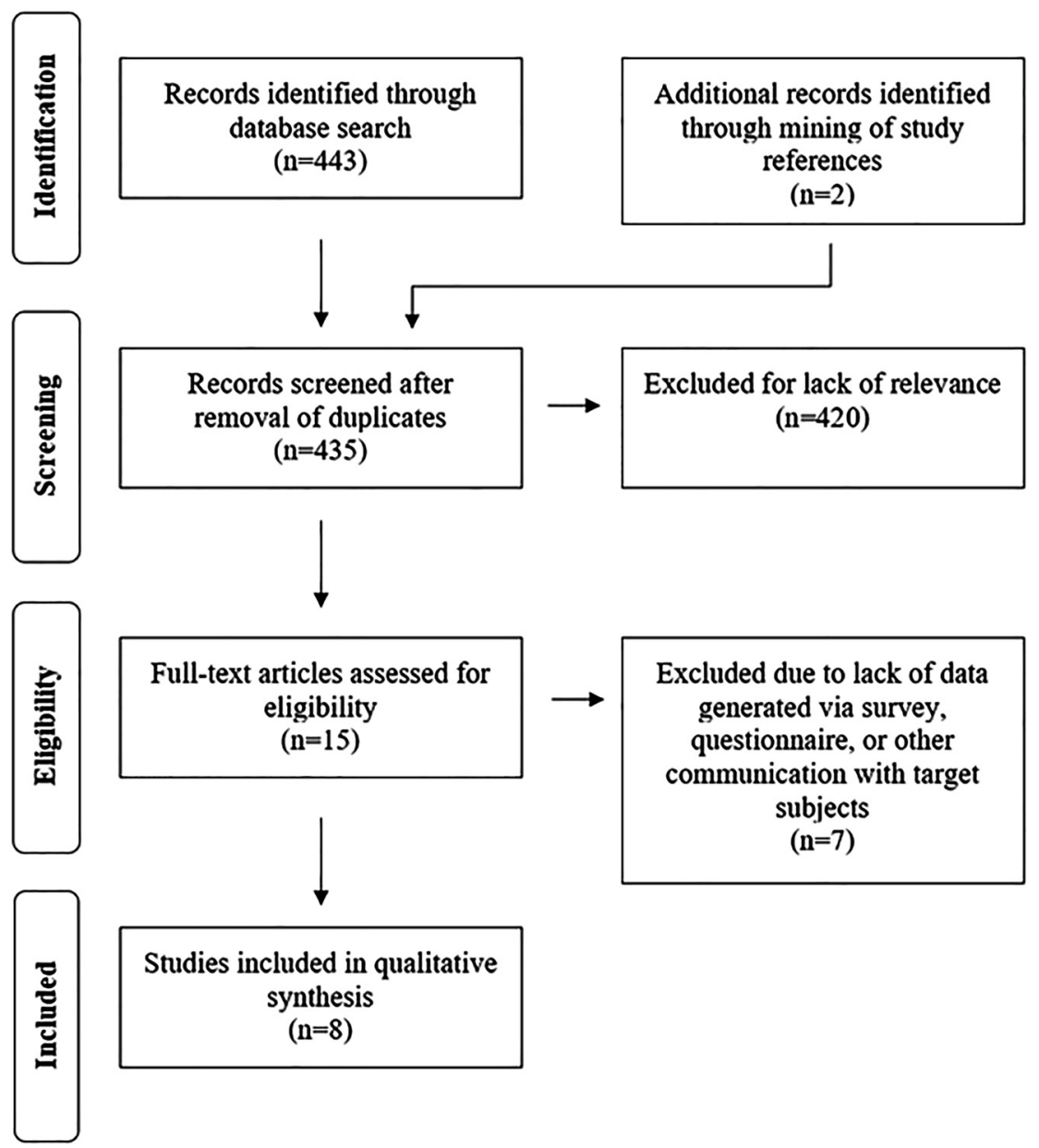

Figure 1: Preferred Reporting Items for Systematic Reviews and Meta-Analyses flowchart of study selection. to identify articles published in English between 1990 and 2020 that sought information from patients, religious leaders, or physicians via surveys or questionnaires related to the impact of religious beliefs or animal-related dietary habits on medication selection. Review articles; opinion pieces; case reports; surveys of persons other than patients, religious leaders, or physicians; and studies published in languages other than English were excluded. The searches were performed in July and August 2020 by four researchers (M.B.B., S.A.R., S.B., S.H.N.). References from full-text articles reviewed were mined to identify additional potential studies for inclusion. Keywords and search strings used for PubMed were as follows: "pharmaceutical preparations" (PubMed Medical Subject Heading [MeSH]) AND "religion and medicine" (MeSH); "porcine” AND "medication selection" AND "religion"; "bovine" AND "medication selection" AND "religion"; "animal" AND "medication selection" AND "religion"; "dietary" AND "medication selection" AND "religion.” Keywords and search strings used for both CINAHL and Cochrane were as follows: "medication" AND "adherence” AND "religion"; "porcine” AND "medication selection" AND "religion"; "bovine" AND "medication selection" AND "religion"; "animal" AND "medication selection" AND "religion." Keywords and search strings used for ProQuest were as follows: "medication adherence" AND "religion"; "porcine" AND "medication selection" AND "religion"; "bovine" AND "medication selection" AND "religion"; "animal" AND "medication selection" AND "religion."

\section{Study selection}

Articles identified in the preliminary database search were initially screened for relevance based on title and abstract where available. After elimination of duplicates, full-text articles were reviewed for presence of experimental or quasi-experimental design in the form of a survey, questionnaire, or communication with predefined target groups including physicians, patients, or religious leaders. Three researchers (M.B.B., S.A.R., S.B.) reviewed the articles. Inclusion was determined by consensus, and no differences in opinion required resolution.

\section{Results}

Preliminary database searches yielded 443 articles. Mining references to identify potentially useful articles yielded two additional studies. Of the 445 articles, 420 were deemed offtopic. After eliminating duplicates, 15 full-text copies of potentially relevant articles were obtained for further scrutiny. Articles were included if they reported conducting a survey or questionnaire of patients, religious leaders, or physicians to ascertain perspectives on acceptability of 
animal-derived medications. Seven articles were excluded due to lack of data generated via survey, questionnaire, or other communication with target subjects.

\section{Data extraction}

Four researchers (M.B.B., S.A.R., S.B., S.H.N.) extracted data, summarized major findings, and synthesized overarching conclusions about acceptability of medications by those surveyed in the studies, as depicted in Table 1.

\section{Characteristics of selected studies}

Risk of bias varied widely across studies. Several studies solicited opinions from religious leaders without providing clear inclusion criteria for selection of subjects or selection of religions. Studies were performed in Australia, several countries in continental Europe, the United Kingdom, and the United States.

\section{Findings of individual studies}

In 2008, Easterbrook and Maddern [22] published a literature review of the impact that Hindu, Islamic, and Jewish faiths may have on use of surgical supplies in Australia. The relative lack of information led them to seek further information via unspecified means of communication with an unspecified number of religious leaders. Jewish and Muslim leaders agreed that use of porcine products normally prohibited by both religions is acceptable when needed to protect life. The chairman of the Hindu Council of Australia indicated that bovine-derived products are considered unacceptable.

A 2005 study by Enoch et al. [12] aimed to discover views of religious leaders in the United Kingdom regarding use of biologic-derived skin substitutes and surgical dressings and to evaluate awareness of healthcare providers about potentially problematic products. A questionnaire regarding 11 biologic products was completed by the 13 leaders of religions that encompass $75 \%$ of the UK population. Products included were derived from humans, pigs, and cows. All religious leaders completed the survey, representing the Anglican sect of Christianity, Buddhism, the Chinese Multicultural Society, Greek Orthodox Christians, Islam, the Jehovah's Witness sect of Christianity, Judaism, Hinduism, the Methodist sect of Christianity, the Quaker sect of Christianity, the Roman Catholic sect of Christianity, the
Salvation Army branch of Christianity, and Sikhism. Many religious leaders (77\%; 10 of 13 surveyed) stressed the importance of patient consent when potentially problematic products are used. Leaders of the Greek Orthodox, Jewish, and Hindu faiths reported that all products were acceptable. Human products were acceptable by Buddhist, Roman Catholic, Salvation Army, Anglican, and Quaker leaders if the donor provided consent, with the caveats that fetal material is unacceptable to Anglican leaders and grafts from neonatal prepuce were unacceptable to Quaker leaders. Islamic leaders would reject porcine-derived products unless there were no other options. The Chinese Multicultural Society expressed concern regarding bovine-derived products for Hindu and Buddhist members and porcine-derived products for Muslim members. Leaders of the Methodist Church stressed that cruelty to animals would be unacceptable, while Buddhist leaders qualified that animal products are acceptable if the animal is not killed solely to obtain the product. The investigators also detailed the knowledge of 73 healthcare providers regarding ingredients of biologic products to find that none knew the origin of all 11 products.

Published in 2013, a study by Eriksson et al. [23] detailed the results of a validated seven-point questionnaire that sought the opinions of religious leaders in 26 European countries. Results from individual sects were pooled to summarize beliefs of six major religions: Buddhism, Christianity, Hinduism, Islam, Judaism, and Sikhism. Ten religious leaders responded. The Sikh leader and the leader of the Hindu Vaishnav sect objected to use of medication or surgical dressing derived from animal sources, though the objection would be waived in emergency situations or in routine treatment where no alternative exists. Muslim leaders rejected porcine-derived products, but waived the objection lacking alternatives or in emergencies. Buddhist, Christian (including Jehovah's Witness), and Jewish leaders did not reject any source of tissue or drug, except for bloodderived products in the case of Jehovah's Witness.

Jenkins et al. [13] investigated acceptance of bovine, human, and porcine-derived surgical mesh in a report published in 2010. The authors sought to survey leaders of major United States religions, the American Vegan Society, and People for the Ethical Treatment of Animals (PETA). Similar to the findings of Eriksson et al. [23], neither the Buddhist leader nor the leaders of various Christian sects objected to animal- or human-derived mesh, with the caveat that many Buddhists of the Theravada sect and Christians of the Seventh Day Adventist sect who practice vegetarianism as part of their faith may individually reject animal-derived products. The leader of the Jehovah's 
Table 1: Summarized findings of included studies.

\begin{tabular}{ll}
\hline Study & Methods \\
\hline Easterbrook and Maddern, 2008 [22] & Communication with Jewish, Muslim, and
\end{tabular}

Easterbrook and Maddern, 2008 [22]
Communication with Jewish, Muslim, and
Hindu leaders in Australia (n unspecified)

\section{Findings}

Porcine products acceptable in Judaism.

Porcine products acceptable in Islam in life-or-death or when no alternative.

Vaishnav sect of Hinduism objects to bovine-derived products.

Enoch et al., 2005 [12]

Questionnaire about 11 products to religious leaders $(n=13)$ and healthcare providers $(n=73)$

Eriksson et al., 2013 [23]

Jenkins et al., 2010 [13]

Koshy et al., $2020[24]$

Mahdi et al., 2016 [25]

Sattar et al., 2004 [26]

Vissamsetti et al., 2012 [27]
Questionnaire to clergy in 26 countries $(n=10)$

Questionnaire to leaders of six US religious and 2 non-religious groups (n unspecified)

Communication with national bodies for major religions in the UK regarding surgical supplies ( $\mathrm{n}$ unspecified)

Survey of American Muslim physicians $(n=255)$

Survey of US patients $(n=100)$ and physicians $(n=106)$ in a US Veteran's Affairs Center

Questionnaire UK patients $(\mathrm{n}=200)$
Greek Orthodox, Jewish, and Hindu leaders found bovine, human, and porcine products unconditionally acceptable.

Methodist leaders stressed that cruelty to animals in obtaining constituents is unacceptable.

Buddhist leaders accept animal products when the animal is not killed solely to obtain the product.

Buddhist, Roman Catholic, Salvation Army, Anglican, and Quaker leaders accept human products with donor consent.

Islamic leaders would reject porcine-derived products unless there were no other option.

Buddhists accept all animal and human products.

Hindu Vaishnav sect rejects porcine and bovine surgical implants.

Sikh sect found bovine products problematic but circumstantially acceptable.

Sunni and Shiite reject porcine-derived medications but circumstantially acceptable.

Christians, Jews, and Theravada Buddhist allow humanand animal-derived products, though Jehovah's Witness forbid blood-derived products.

Hindu and Sikh leaders allow human-derived products if the donor had given consent.

Christian, Islamic, and Jewish sect leaders reported acceptance of all tissue types.

Buddhist leader reported that individual Buddhists may reject animal products.

Hindu leader reported avoidance of animal-derived tissue.

Most religious leaders report that life-or-death circumstances would override restrictions.

All religious leaders found human-derived products acceptable.

Buddhist, Hindu, Jain, and Sikh reject bovine products with circumstantial exception.

Buddhist, Hindu, Islamic, Jain, and Sikh object to porcine products with circumstantial exception.

$76.2 \%$ would recommend a porcine-based vaccination in a scenario-based survey.

13 of the patients surveyed adhered to faiths with beliefs that define acceptability of animal products.

Of those, nine thought it important to be informed by their physician of a medication containing a restricted ingredient.

$88 \%(n=176)$ of patients adherent to religions with dietary restrictions preferred non-animal-derived medication ingredients. 
Witness sect emphasized that adherents to this faith would reject blood-derived products. Hindu leaders reported that most adherents would reject animal-products, and their belief in cremation of human remains may prohibit use of cadaver parts. Islamic leadership indicated no prohibitions for bovine, porcine, or human products in surgery, though the authors recommend that many Muslims would prefer non-porcine products. Leadership in the PETA group could not endorse any practice that harmed animals, though they strongly advocated for human-derived products that are ethically obtained.

In the UK, a surgical group contacted leaders of major religions after a patient objection to an animal-derived product in surgery highlighted the need for informed consent [24]. The authors stated neither their methodology nor the number of participants surveyed. They reported that Buddhist, Christian, Hindu, Islamic, Jain, and Jewish leaders all found human-derived surgical products acceptable where donor consent has been obtained. All leaders reported that objections may be waived in lifesaving circumstances or where no alternates are available. Buddhist, Hindu, Jain, and Sikh leaders reported that routine use of bovine and porcine surgical products would be unacceptable. Christian and Jewish leaders reported acceptability of both bovine and porcine products.

A scenario-based survey of American Muslim physicians was published by Mahdi et al. in 2016 [25]. The scope of this study covered ethically controversial medical procedures, including use of a porcine-derived vaccine. Of 244 respondents, 186 (76.2\%) would recommend the porcinederived vaccine presented in the scenario.

A survey of 100 patients and 106 physicians at the Veterans Affairs Medical Center in Omaha, Nebraska, focused on awareness of animal-derived ingredients and perspective on need for informed consent from patients [26]. Thirteen of the studied patients belonged to faiths with dietary restrictions. Of these 13 patients, 9 (69.2\%) were not aware that medications might contain prohibited beef or pork ingredients, 9 (69.2\%) thought it important to be informed before a medication containing pork or beef was prescribed, and $6(46.2 \%)$ would be willing to pay more for an alternate product that did not contain prohibited ingredients. Of the physicians surveyed, only 34 (32\%) were aware that medications might contain ingredients that were prohibited by patients' religions, 75 (70\%) thought it important to inform patients when such medications were prescribed, while only $5(4 \%)$ reported doing so.

A patient questionnaire found that 200 of 500 patients surveyed in a UK urology practice avoided animal products [27]. Of these 200 patients, 176 (88\%) declared a preference for vegetarian-based oral medications; 150 (85.2\%) of these patients would not routinely take any oral medication containing an animal product, though 100 of the 176 (56.8\%) would do so if no alternative was available. The authors found that the number of patients stating preference for vegetarian medications was double that expected based upon community religious demographics.

\section{Discussion}

\section{Major U.S. religions associated with beliefs that may impact medication selection}

Nearly $5.5 \%$ of the United States' 330 million citizens identify with six major religious sects with teachings that may impact medication selection: Judaism, Islam, Buddhism, Hinduism, and the Jehovah's Witness and Seventh Day Adventist sects of Christianity [12, 28]. While there are general lifestyle guidelines within each of these religions, followers' beliefs are not homogenous; therefore, the "spiritual history" is essential to identify the convictions and desires of each individual patient in a cultural humility-based approach. Additionally, in the context of medical ethics and informed consent, physicians must be equipped to provide patients with alternative compliant therapies [11, 26]. Where uncertainty exists, spiritual or religious leaders may offer guidance in interpretation of sacred texts as it applies to patient care [13, 29, 30]. Leaders of many faiths waive restrictions during emergency situations where there are no viable alternatives [23]. Table 2 summarizes religious views that may more commonly impact medication selection for common religious sects in the United States.

\section{Potentially problematic drugs and drug products}

Both active ingredients and inert excipients of pharmaceuticals may contain animal-derived ingredients. Table 3 lists the origins of common products available in the United States that are directly derived from animals. In the United States, drug companies are not required to report the origins of excipients. This represents a major limitation to meaningful discussion with patients who are adherent to avoidance of specific animal sources.

As seen in Table 3, all heparinoids except the pentasaccharide fondaparinux are porcine-derived and thus may be problematic for adherents of Islam, Judaism, and those who practice vegetarianism and veganism. The 
Table 2: Common U.S. religious sects with relevant restrictions.

\begin{tabular}{lrl}
\hline Religion [28] & \% of U.S. population & Restrictions that may impact medication selection \\
\hline $\begin{array}{l}\text { Buddhism } \\
\text { Christian sects: }\end{array}$ & $0.7 \%$ & Vegetarianism and veganism are common. \\
$\quad$ Jehovah's Witness & $0.8 \%$ & Blood and blood products are problematic. \\
$\quad$ Seventh Day Adventism & $0.5 \%$ & Vegetarianism is common. \\
Hinduism & $0.4 \%$ & $\begin{array}{l}\text { Vegetarianism is common. Bovine products are generally avoided. } \\
\text { Islam }\end{array}$ \\
& $0.9 \%$ & $\begin{array}{l}\text { Vegetarianism is common. Haram (forbidden) include alcohol, animal-derived } \\
\text { enzymes, porcine products, meat from carnivores, and L-cysteine derived }\end{array}$ \\
& & $\begin{array}{l}\text { from human hair. } \\
\text { Judaism }\end{array}$ \\
& $1.9 \%$ & $\begin{array}{l}\text { Porcine products, products containing both meat and milk, and products from fish } \\
\text { that lack either fins or scales are generally avoided. }\end{array}$ \\
\hline
\end{tabular}

injectable direct thrombin inhibitors bivalirudin and argatroban are animal-free.

In the category of hormones, it is fortunate that insulinderived from modern recombinant DNA technology is animal-free. Unfortunately, there are no truly animal-free oral thyroid hormone replacement products due to excipients used in the tablet formations. Levothyroxine sodium lyophilized powder is animal-free but requires intravenous administration.

Immunoglobulin antitoxins for Crotalidae and Micrurus envenomation are ovine and equine sourced, respectively; there are no animal-free options for these critical life-saving medications. Similarly, digoxin immune fab is produced in sheep. Most monoclonal antibodies used in medicine are derived through recombinant gene technology. Nonetheless, they may be problematic due to use of animal cell lines for production (e.g., trastuzumab [Herceptin ${ }^{\circledR}$ ] in Chinese hamster ovary cells) and due to the presence of other animal proteins introduced during production.

Vaccine production often incorporates many animalderived products. Cell lines for production, excipients, and nutritional supplements for cell culture are often problematic including bovine-derived trypsin, human or bovine albumin, and use of aborted fetal cell lines. Due to the healthpreserving nature of immunization, religious scholars often waive prohibitions for vaccines [11]. Such concerns regarding the halal status of the SARS-CoV-2 vaccine have made recent headlines. A media investigation revealed that Pfizer's SARS-CoV-2 vaccine is sourced from Halal products, with lipid components derived from chicken egg [32]. The Vatican recently announced that COVID-19 vaccines are morally acceptable even if aborted fetal cell lines are used in their research and production process [33].

Many inert excipients used in dosing formulations are potentially problematic. Capsule formulations commonly contain gelatin, which is a general term for a mixture of proteins obtained via hydrolysis of bovine or porcine bone, or from bovine, piscine, or porcine skin [11, 30]. Demand for animal-free products has increased availability of vegetarian capsules made with hypermellose [32]. Lactose is a common excipient in tablets, capsules, dry-powder inhalers, and injections; it has been traditionally derived from milk via extraction using bovine rennet. Some manufacturers use a non-rennet process, but the origin of the sugar is still bovine milk, which may still be problematic for some [11]. Stearic acid and derivatives are often generated from rendered bovine, porcine, or ovine fats, though plant-sourced stearate is sometimes used. Unfortunately, the source of stearate is not indicated on most labels [11]. Other common problematic ingredients include albumin, which may be either human or bovine in origin; insectderived carmine, cochineal, and shellac; bovine-derived casein; bovine or ovine deoxycholate; piscine-derived protamine; and tallow, which may be bovine, ovine, or porcine in origin [9-11].

\section{Limitations}

Many of the existing studies were based upon unstructured communications rather than validated surveys and often focused on surgical products rather than systemically ingested medications. Additionally, very few investigations have been performed to explore overarching preferences and beliefs in the United States; the domain of provider awareness in the U.S. remains largely unexplored. Significant weaknesses of this review include a large heterogeneity in methodologies, the small number and limited variety of participants targeted for interview, and the variable foci of the queries. The acceptability of animal- or human-derived products is an individual patient decision. The scope of this study was limited to the quantifiable domain of cultural competency; by its nature, a systematic scoping review can neither inform of 
Table 3: List of potentially problematic medications by class and potential alternatives [14, 15, 31].

\begin{tabular}{|c|c|}
\hline Animal-derived product* & Animal-free product* \\
\hline \multicolumn{2}{|l|}{ Heparinoids } \\
\hline $\begin{array}{l}\text { Unfractionated heparin, dalteparin }\left(\text { Fragmin }^{\circledR}\right) \text {, } \\
\text { enoxaparin (Lovenox }{ }^{\circledR} \text { ) (porcine) }\end{array}$ & Fondaparinux (Arixtra ${ }^{\circledR}$ ) \\
\hline \multicolumn{2}{|l|}{ Hormones } \\
\hline Conjugated estrogens (equine) & Estradiol topical gel, vaginal ring \\
\hline Corticotropin (Acthar $\left.{ }^{\circledR}\right)$ (porcine) & None \\
\hline Dessicated thyroid (Armour Thyroid ${ }^{\circledR}$ ) (porcine) & $\begin{array}{l}\text { Levothyroxine injection, levothyroxine tablets contain stearate, } \\
\text { lactose, or gelatin }\end{array}$ \\
\hline Non-human insulins (various sources) & Recombinant insulins \\
\hline Pancreatic enzymes (various sources) & None \\
\hline \multicolumn{2}{|l|}{ Immunoglobulins } \\
\hline Crotalidae antivenin $\left(\mathrm{CroFab}^{\circledR}\right)$ (ovine) & None \\
\hline Digoxin immune globulin (Digibind ${ }^{\circledR}$ ) (ovine) & None \\
\hline Micrurus fulvius antivenom (equine) & None \\
\hline \multicolumn{2}{|l|}{ Lipid emulsion-containing medications } \\
\hline Propofol (Diprivan ${ }^{\circledR}$ ) (egg) & Fospropofol (Lusedra $\left.{ }^{\circledR}\right)$ \\
\hline Lipid emulsion (egg) & None \\
\hline \multicolumn{2}{|l|}{ Surfactant } \\
\hline $\begin{array}{l}\text { Poractant alpha }\left(\text { Curosurf }^{\circledR}\right)\left(\text { porcine); calfactant }\left(\text { Infasurf }{ }^{\circledR}\right) \text {, }\right. \\
\text { beractant }\left(\text { Survata }^{\circledR}\right) \text { (bovine) }\end{array}$ & None \\
\hline \multicolumn{2}{|l|}{ Vaccines } \\
\hline $\begin{array}{l}\left.\text { DTaP-IPV (Quadracel }{ }^{\circledR}\right) \text {, DTaP-IPV/Hib }\left(\text { Pentacel }^{\circledR}\right) \text { (Bovine); } \\
\text { Hib }\left(\text { Hiberix }^{\circledR}\right) \text { (lactose) }\end{array}$ & $\begin{array}{l}\text { DTaP }\left(\text { Infanrix }{ }^{\circledR}\right) \text {, DTaP-IPV }\left(\text { Kinrix }^{\circledR}\right) \text {, DTaP-HepB-IPV }\left(\text { Pediarix }^{\circledR}\right) \\
\left.{\text { Hib }\left(\text { ActHIB }^{\circledR}, \text { PediavxHIB }\right.}^{\circledR}\right)\end{array}$ \\
\hline Influenza vaccines (most contain egg) & None \\
\hline \multicolumn{2}{|l|}{ Flublok $^{\circledR}$ (insect) } \\
\hline \multicolumn{2}{|l|}{ Flucelvax ${ }^{\circledR}$ (canine) } \\
\hline Hepatitis A (Havrix ${ }^{\circledR}$ ) (aborted human fetal cell line), Vaqta ${ }^{\circledR}$ (bovine) & None \\
\hline Hepatitis B (Heplisav- $\left.{ }^{\circledR}\right)$ (bovine or ovine) & Engerix- $\mathrm{B}^{\circledR}$, Recombivax $^{\circledR}$ \\
\hline Hep A/Hep B (Twinrix ${ }^{\circledR}$ ) (aborted human fetal cell line) & None \\
\hline $\begin{array}{l}\text { Measles, mumps, rubella vaccine }\left(M M R I^{\circledR}\right) \\
\text { (bovine, gelatin - unspecified source) }\end{array}$ & None \\
\hline $\begin{array}{l}\text { Measles, mumps, rubella, varicella }\left(\text { ProQuad }^{\circledR} \text { ) }\right. \\
\text { (aborted human fetal cell line, bovine) }\end{array}$ & None \\
\hline $\begin{array}{l}\text { Rabies }\left(\text { Imovax }{ }^{\circledR}\right)\left(\text { Human albumin); }\left(\text { RabAvert }{ }^{\circledR}\right)\right. \\
\text { (human albumin, bovine, chicken protein) }\end{array}$ & None \\
\hline Rotavirus vaccine (RotaTeq ${ }^{\circledR}$ ) (bovine) & Rotarix $^{\circledR}$ - contains porcine circovirus type 1 and 2 DNA \\
\hline $\begin{array}{l}\text { Varicella }\left(\text { Varivax }^{\circledR}, \text { Zostavax }^{\circledR}\right) \text { (aborted human fetal cell line, bovine) } \\
\left(\text { Shingrix }^{\circledR}\right) \text { (cholesterol, host cell proteins - source unspecified) }\end{array}$ & None \\
\hline
\end{tabular}

*Listing of a brand is not an endorsement, but rather offers an animal-free option at the time this article was written. Product composition may change. Please see body of text for resources to make certain products are animal-free.

individual patient preference nor help individual practitioners develop the self-awareness and active listening skills needed for cultural humility.

\section{Further drug ingredient-related information}

While not specific to products available in the United States, the Australian Queensland Health Guidelines [15] are comprehensive and are available online. The CDC Pink Book [31] lists vaccine excipients and also may be accessed online. Drug package inserts list individual ingredients and Section 13 of the official insert offers the product description that lists ingredients. Different manufacturers may use different excipients in their product, so the manufacturer-specific product insert must be consulted. The United States Library of Medicine [34] hosts a searchable online library of medication labels online.

\section{Conclusions}

Development of cultural humility is an ongoing process of awareness that is integral to patient-centered care. Cultural competency provides a measurable but generic basis of 
knowledge from which this awareness can grow. Taking a spiritual history can afford the provider with an opportunity to establish trust and familiarity while simultaneously learning from the patient which aspects of the patient's belief system impact their treatment plan. Knowledge of animal-derived ingredients may help open the conversation, particularly for those patients belonging to religious sects with doctrines that define appropriate use of humanor animal-derived products. Further formal study is needed to explore more fully the extent to which religious beliefs may impact selection of animal- or human-derived medications. Guidelines developed from this knowledge may aid in identifying individual patients with whom the discussion may be particularly relevant.

Acknowledgements: The authors thank W. Cathy Eldahan, MPA, Director of Inclusion and Diversity Engagement at LMU-DCOM, for reviewing the manuscript and providing data and knowledge in verbal form during the preparation. We also acknowledge the Social and Gender Equality Club at LMU-DCOM for its role in the conception of this project. Research funding: None declared.

Author contributions: All authors provided substantial contributions to conception and design as well as acquisition of data; all authors drafted the article and revised it critically for important intellectual content; all authors gave final approval of the version of the article to be published; all authors agree to be accountable for all aspects of the work in ensuring that questions related to the accuracy or integrity of any part of the work are appropriately investigated and resolved.

Competing interests: Authors state no conflict of interest.

\section{References}

1. Abdulla A, Hossain M, Barla C. Toward comprehensive medicine: listening to spiritual and religious needs of patients. Gerontol Geriatr Med 2019;5. https://doi.org/10.1177/2333721419843703.

2. Paal $P$, Frick $E$, Roser T, Jobin G. Expert discussion on taking a spiritual history. J Palliat Care 2017;32:19-25.

3. Balboni TA, Vanderwerker LC, Block SD, Elizabeth Paulk M, Lathan CS, Peteet JR, et al. Religiousness and spiritual support among advanced cancer patients and associations with end-of-life treatment preferences and quality of life. J Clin Oncol 2007;25:555-60.

4. O'Sullivan M. Holistic health care and spiritual self-presence. Religions 2016;7:10.

5. Whitley R. Religious competence as cultural competence. Transcult Psychiatry 2012;49:245-60.

6. Borneman T, Ferrell B, Puchalski CM. Evaluation of the FICA Tool for spiritual assessment. J Pain Symptom Manage 2010;40:163-73.

7. Lucchetti G, Bassi RM, Lucchetti AL. Taking spiritual history in clinical practice: a systematic review of instruments. Explore 2013; 9:159-70.
8. Koenig HG. STUDENTJAMA. Taking a spiritual history. J Am Med Assoc 2004;291:2881.

9. Corfield L, Granne I. Ethical and practical considerations in prescribing animal-derived medication. Postgrad Med J 2012;88: 497-8.

10. Rodger D, Blackshaw BP. Using animal-derived constituents in anaesthesia and surgery: the case for disclosing to patients. BMC Med Ethics 2019;20:14.

11. Implications of religious and cultural beliefs on selection of medicines. Drug Ther Bull 2016;54:45-8.

12. Enoch S, Shaaban H, Dunn KW. Informed consent should be obtained from patients to use products (skin substitutes) and dressings containing biological material. J Med Ethics 2005;31:2-6.

13. Jenkins ED, Yip M, Melman L, Frisella MM, Matthews BD. Informed consent: cultural and religious issues associated with the use of allogeneic and xenogeneic mesh products. J Am Coll Surg 2010; 210:402-10.

14. The Task Force on Medicines Partnership, NHS, United Kingdom. Drugs of porcine origin and their clinical alternatives: an introductory guide. 2004. Available from: http://archive.mcb.org. uk/wp-content/uploads/2015/12/Drugs-Derived-From-Pigs-andtheir-Clinical-Alternatives_Booklet.pdf [Accessed 24 May 2020].

15. Health Department, Queensland Government. Medicines/ pharmaceuticals of animal origin. Document \#: QH-GDL-954: 2013. Reviewed on January 4, 2019 https://www.health.qld.gov. au/_data/assets/pdf_file/0024/147507/qh-gdl-954.pdf [Accessed 24 May 2020].

16. Resneck J. Information regarding animal-derived medications. Resolution 515-A-18. American medical association resolution, annual meeting 2018. https://www.ama-assn.org/system/files/ 2018-11/a18-reference-committee-reports.pdf [Accessed 10 May 2020].

17. Kumagai AK, Lypson ML. Beyond cultural competence: critical consciousness, social justice, and multicultural education. Acad Med 2009;84:782-7.

18. Sprik P, Gentile D. Cultural humility: a way to reduce LGBTQ health disparities at the end of life. Am J Hosp Palliat Care 2020; 37:404-8.

19. Miller S. Cultural humility is the first step to becoming global care providers. J Obstet Gynecol Neonatal Nurs 2009;38:92-3.

20. Foronda C. A theory of cultural humility. J Transcult Nurs 2020;31:7-12.

21. Moher D, Liberati A, Tetzlaff J, Altman DG, PRISMA Group. Preferred reporting items for systematic reviews and metaanalyses: the PRISMA statement. PLoS Med 2009;6:e1000097.

22. Easterbrook C, Maddern G. Porcine and bovine surgical products: Jewish, Muslim, and Hindu perspectives. Arch Surg 2008;143: 366-70.

23. Eriksson A, Burcharth J, Rosenberg J. Animal derived products may conflict with religious patients' beliefs. BMC Med Ethics 2013;14:48.

24. Koshy RM, Kane EG, Grocock C. A review of the use of biological mesh products in modern UK surgical practice: a religious and cultural perspective. Ann R Coll Surg Engl 2020; 102:566-70.

25. Mahdi S, Ghannam O, Watson S, Padela Al. Predictors of physician recommendation for ethically controversial medical procedures: findings from an exploratory national survey of American Muslim physicians [published correction appears in J Relig Health. 2016 Jun;55(3):1120-1]. J Relig Health 2016;55: 403-21. 
26. Sattar SP, Ahmed MS, Madison J, Olsen DR, Bhatia SC, Ellahi S, et al. Patient and physician attitudes to using medications with religiously forbidden ingredients. Ann Pharmacother 2004;38: 1830-5.

27. Vissamsetti B, Payne M, Payne S. Inadvertent prescription of gelatin-containing oral medication: its acceptability to patients. Postgrad Med J 2012;88:499-502.

28. Pew Foundation. Major religions in US. https://www.pewforum. org/religious-landscape-study/ [Accessed 10 May 2020].

29. Seventh-day adventist church manual, 19th ed. Secretariat general conference of seventh-day adventists. https://www. adventist.org/fileadmin/adventist.org/files/articles/ information/seventh-day-adventist-church-manual_2015_ updated.pdf [Accessed 23 Nov 2019].

30. My Jewish learning. 70/FACES media. Kosher food: what makes food kosher or not. https://www.myjewishlearning.com/article/ kosher-food/ [Accessed 23 Nov 2019].
31. Centers for Disease Control and Prevention. Epidemiology and prevention of vaccine-preventable diseases, 13th ed; 2015. https://www.cdc.gov/vaccines/pubs/pinkbook/downloads/ table-of-contents.pdf [Accessed 10 May 2020].

32. Milko V. Concern among Muslims over halal status of COVID-19 vaccine. US News \& World Report; 2020. https://www.usnews.com/ news/world/articles/2020-12-20/concern-among-muslims-overhalal-status-of-covid-19-vaccine [Accessed 21 Dec 2020].

33. Wamsley L. Vatican OKs receiving COVID-19 vaccines, even if research involved fetal tissue. NPR coronavirus update website December 21, 2020. https://www.npr.org/sections/coronaviruslive-updates/2020/12/21/948806643/vatican-oks-receivingcovid-19-vaccines-even-if-research-involved-fetal-tissue [Accessed 21 Dec 2020].

34. Daily Med. U.S. Library of Health website; 2020. https:// dailymed.nlm.nih.gov/dailymed/advanced-search.cfm [Accessed 10 May 2020]. 